\title{
Symbols and Myths of European Union Transnational Solidarity
}

Manners, lan James

Published in:

Transnational Solidarity

DOI:

10.1017/9781108766593

Publication date:

2020

Citation for published version (APA):

Manners, I. J. (2020). Symbols and Myths of European Union Transnational Solidarity. In H. Krunke, H.

Petersen, \& I. Manners (Eds.), Transnational Solidarity: Concept, Challenges and Opportunities (pp. 76-100).

Cambridge University Press. https://doi.org/10.1017/9781108766593 


\section{Symbols and Myths of European Union Transnational Solidarity}

IAN MANNERS

\section{Introduction}

The treaties of European Union (EU) contain twenty-nine references to 'solidarity' with a wide variety of meanings and consequences for the study of transnational solidarity. This contribution takes a step back from the policy detail of these treaty- and policy-based understandings of solidarity to consider the constitutive effects of EU symbols and myths in a wider understanding of transnational solidarity within, across, and beyond the EU. The EU's Europe Day Poster celebrating '50 Years of Solidarity, Prosperity and Peace' on 9 May 2000 illustrates (Figure 5.1) that the status of solidarity in the $\mathrm{EU}$ is one of considerable importance in terms of symbols and myths of EU transnational solidarity.

This chapter explores the symbols and myths of EU transnational solidarity through a threefold analysis of transnational solidarity within, across, and beyond the EU. Based on post-Cold War study of the EU in global politics over the past three decades, the chapter compares and contrasts transnational solidarity from communitarian and cosmopolitan perspectives before advocating a cosmopolitical understanding of EU transnational solidarity in a global context. The chapter proceeds by delineating and theorising the concepts used, including symbols and myths, European integration, and transnational solidarity in order to prepare the ground for the next three analytical sections. Section 2 examines transnational solidarity within the EU by looking at symbols and myths of communitarian, cosmopolitan, and cosmopolitical solidarities. Section 3 looks across the borders of the EU to consider the symbols and myths of communitarian, cosmopolitan, and cosmopolitical solidarities within the European neighbourhood. Section 4 goes beyond the EU to analyse the symbols and myths of communitarian, cosmopolitan, and cosmopolitical solidarities 


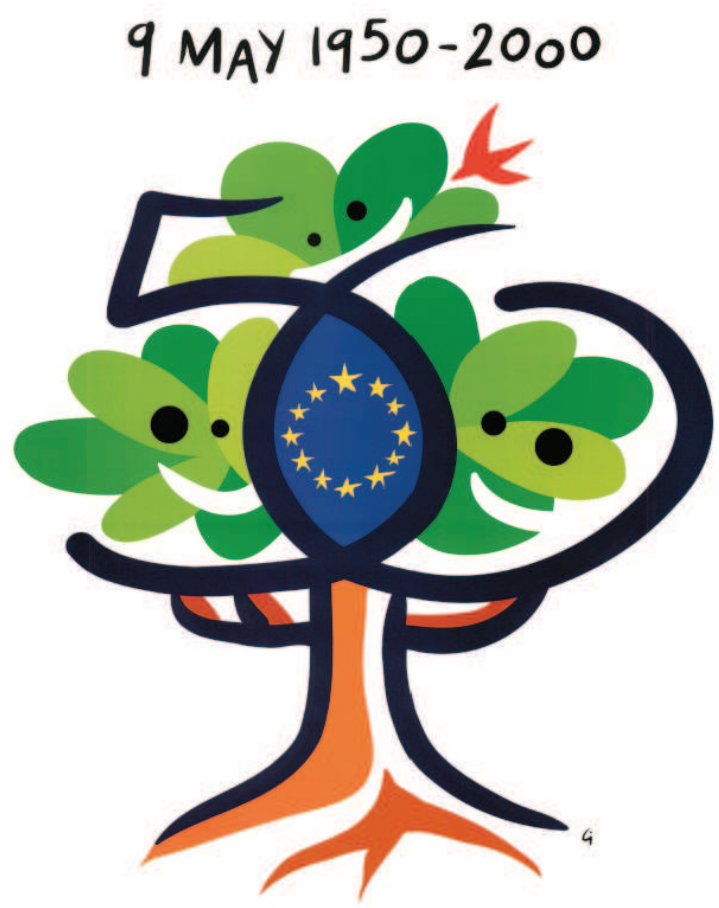

50 YEARS OF SOLIDARITY, PROSPERITY AND PEACE

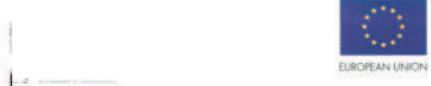

Figure 5.1 European Union, Europe Day Poster, $2000^{1}$

with distantly situated others through EU external actions. The chapter concludes by arguing the need to clearly identify, in line with Carol Gould, ${ }^{2}$ transnational EU solidarities as overlapping networks of relations that share and support actions to eliminate oppression or reduce suffering. It is furthered argued that cosmopolitical solidarities that network and share

${ }^{1}$ European Union, '50 Years of Solidarity, Prosperity and Peace, 9 May 1950-2000' (2000) Europe Day Poster, available at: https://europa.eu/european-union/about-eu/symbols/ europe-day_en).

2 C. Gould, 'Transnational solidarities', Journal of Social Philosophy, 38(1) (2007), 148; C. Gould, 'Solidarity between the national and the transnational: what do we owe to “outsiders"?', in H. Krunke, H. Petersen and I. Manners (eds.), Transnational Solidarity (Cambridge: Cambridge University Press, 2020). 
global ethics with local politics are more likely to take actions in concert that are caring and empathic towards distantly situated others.

The chapter draws upon material from a four-year project on symbols and myths in European integration to analyse the roles of symbols and images, myths and narratives, in this solidarity. Collective symbols and myths are fundamental to our understanding of issues such as European social solidarity, citizens feeling of belonging to the EU, political advocacy for and resistance to European integration, and concrete political actions in global politics. It is important to clarify that symbols are understood not just as the official 'icons' of the EU (the flag, the motto, the anthem, the day, or the euro), but as including official and nonofficial images and representations of the EU. ${ }^{3}$ Similarly, myths are understood not as imaginary or unreal folklore, but as cultural and political narratives that provide meaning of the EU in society. ${ }^{4}$ Symbols and myths include performative 'rituals' (such as ceremonies and commemorations), 'totems' (such as the capital of culture), and 'taboos' (such as exiting the euro/EU). These rituals and practices of meaning-making ensure that symbols and images, myths and narratives are represented and inscribed with particular understandings for the producers and consumers of European (dis)integration. The final step is to realise that such symbols and images, myths and narratives, rituals and practices are read, and must be interpreted, through political psychology. ${ }^{5}$

The chapter compares and contrasts symbols and myths of EU transnational solidarity within, across, and beyond the EU. The chapter makes a unique contribution to the volume by raising questions about communitarian, cosmopolitan, and cosmopolitical understandings of solidarity and the way they travel over distance within, across, and beyond the EU. European integration is understood as the social, economic, and political processes of mutual accommodation and inclusion by European states and peoples. ${ }^{6}$ This definition of European integration is more accommodating and inclusive to social, economic, and political processes than the conventional definition of political integration defined by one of the

${ }^{3}$ I. Manners, 'Symbolism in European Integration', Comparative European Politics, 9(3) (2011), 243.

4 I. Manners, 'Global Europa: Mythology of the European Union in World Politics', Journal of Common Market Studies, 48(1) (2010),67; I. Manners and P. Murray, 'The end of a noble narrative? European integration narratives after the Nobel Peace Prize', Journal of Common Market Studies, 54(1) (2016), 185.

5 I. Manners, 'Political psychology of European integration: the (re)production of identity and difference in the Brexit debate' Political Psychology, 39(6) (2018), 1,213.

${ }^{6}$ Ibid., p. 1,214 
earliest theorists of European integration, Miriam Camps, as a 'new form of "action in common" among governments' merging their 'sovereignties to form a new political unit'. ${ }^{7}$ The notion of solidarity in the EU has become expansive in the seventy years since the Schuman Declaration (1950) and Treaty of Paris (1951) aimed at taking 'concrete actions which create a real solidarity'. This diversity of solidarities is captured in the Treaty of European Union's (TEU) emphases on 'solidarity between ... peoples', 'solidarity ... between women and men', 'solidarity between generations', 'solidarity among Member States' and 'solidarity ... among peoples [of the wider world]' in the Preamble, and Articles 2 and $3 .{ }^{8}$ With twenty-nine references to solidarity in the TEU and Treaty on the Functioning of the EU consolidated after the Treaty of Lisbon, it is clear that the term is used in a wide variety of ways and contexts. For example, previous research on the EU's normative power over the past two decades has analysed the promotion of social solidarity, in particular through development and trade policies, in global politics. ${ }^{9}$

As the other contributions to the volume demonstrate, conceptualising and defining transnational solidarity within and without the EU is challenging, especially given the expansive understandings of solidarity found in the EU. What is equally clear is that these understandings of solidarity depend heavily on positions taken within communitarian and cosmopolitan views of the world. In order to address these questions throughout the rest of the chapter, Carole Gould's conception of transnational solidarities is adopted, understood in terms of 'overlapping networks of relations between individuals (or groups) and distantly situated others (again, individuals or groups), in which the former aim to support these latter through actions to eliminate oppression or reduce suffering. ${ }^{10}$ This conception of transnational solidarity has four particulars of interest in this chapter: (1) it consists of networks of relations between individuals or groups; (2) it has shared goals of eliminating

7 M. Camps, 'The European Common Market and American policy', Memorandum No. 11, Center of International Studies, Princeton University (1956), p.3 and M. Camps, 'The European Common Market and free trade area: a progress report', Memorandum No. 15, Center of International Studies, Princeton University (1957), p.7 in I. Manners, 'European communion: political theory of European Union', Journal of European Public Policy, 20(4) (2013), 473.

8 TEU 2016: Art. 5 and 17.

9 I. Manners, 'Normative power Europe: a contradiction in terms?', Journal of Common Market Studies, 40(2) (2002),235, 242; I. Manners, 'Normative ethics of the European Union', International Affairs, 15(1) (2008), 45, 53.

10 C. Gould, 'Solidarity between the national and the transnational'. 
oppression or reducing suffering; (3) it is based on empathy between distantly situated others and; (4) it takes place through taking action in support of others. ${ }^{11}$ Having set out the central concepts of symbols and myths, European integration, and transnational solidarity, the next section proceeds to use these ideas to analyse symbols and myths of transnational solidarity within the EU.

\section{Transnational Solidarity within the EU}

Discussions of solidarity in the EU have grown exponentially in the two decades since the Treaty of Maastricht. ${ }^{12}$ Similarly, the growth of normative political theory and critical social theory, applied to the study of global ethics and global justice of the EU has occurred at the same time. ${ }^{13}$ While most accounts of EU solidarity tend to fall within communitarian approaches based on mutual concern, a few stray into cosmopolitan approaches emphasising reciprocal arrangements of mutual aid and duties. In almost all cases, this dichotomisation into communitarian versus cosmopolitan approaches tend to rule out the possibility of other approaches such as transnational solidarity or

11 Gould, 'Transnational solidarities', 148.

12 F. Scharpf, 'The European social model', Journal of Common Market Studies, 40(4) (2002), 645; J. White, 'Rethinking transnational solidarity in the EU', Perspectives, 20 (2003), 40; G. De Burca (ed.), EU Law and the Welfare State: In Search of Solidarity (Oxford: Oxford University Press, 2005); M. Krajewski, U. Neergaard, and J. van de Gronden (eds.), The Changing Legal Framework for Services of General Interest in Europe: Between Competition and Solidarity (The Hague:Asser Press, 2009); M. Ross and Y. BorgmannPrebil (eds.), Promoting Solidarity in the European Union (Oxford: Oxford University Press, 2010); J. Hayward and R. Wurzel (eds.), European Disunion: Between Sovereignty and Solidarity (London: Palgrave, 2012).

13 I. Manners, 'The European Union as a normative power: a response to Thomas Diez', Millennium, 35(1) (2006), 167; I. Manners, 'European Union, normative power and ethical foreign policy', in D. Chandler and V. Heins (eds.), Rethinking Ethical Foreign Policy: Pitfalls, Possibilities and Paradoxes (London: Routledge, 2006), p. 116; I. Manners, 'Another Europe is possible: critical perspectives on European Union politics', in K. E. Jørgensen, M. Pollack, and B. Rosamond (eds.), Handbook of European Union Politics (London: Sage, 2007), p. 77; I. Manners, 'The European Union's normative power: critical perspectives and perspectives on the critical', in R. Whitman (ed.), Normative Power Europe: Empirical and Theoretical Perspectives (London: Palgrave, 2011), p. 226; I. Manners, 'Un-national normative justification for European Union foreign policy', in J. Neyer and A. Wiener (eds.), Political Theory of the European Union (Oxford: Oxford University Press, 2011), p. 47; I. Manners, 'European communion: political theory of European Union', Journal of European Public Policy, 20(4) (2013), 473; I. Manners, 'Assessing the decennial, reassessing the global: understanding European Union normative power in global politics', Cooperation and Conflict, 48(2) (2013), 304-29. 
cosmopolitics. ${ }^{14}$ As the recent European Commission booklet on 'Solidarity in Europe: Alive and Active' illustrates (Figure 5.2) solidarity within the EU has at least three different meanings communitarian

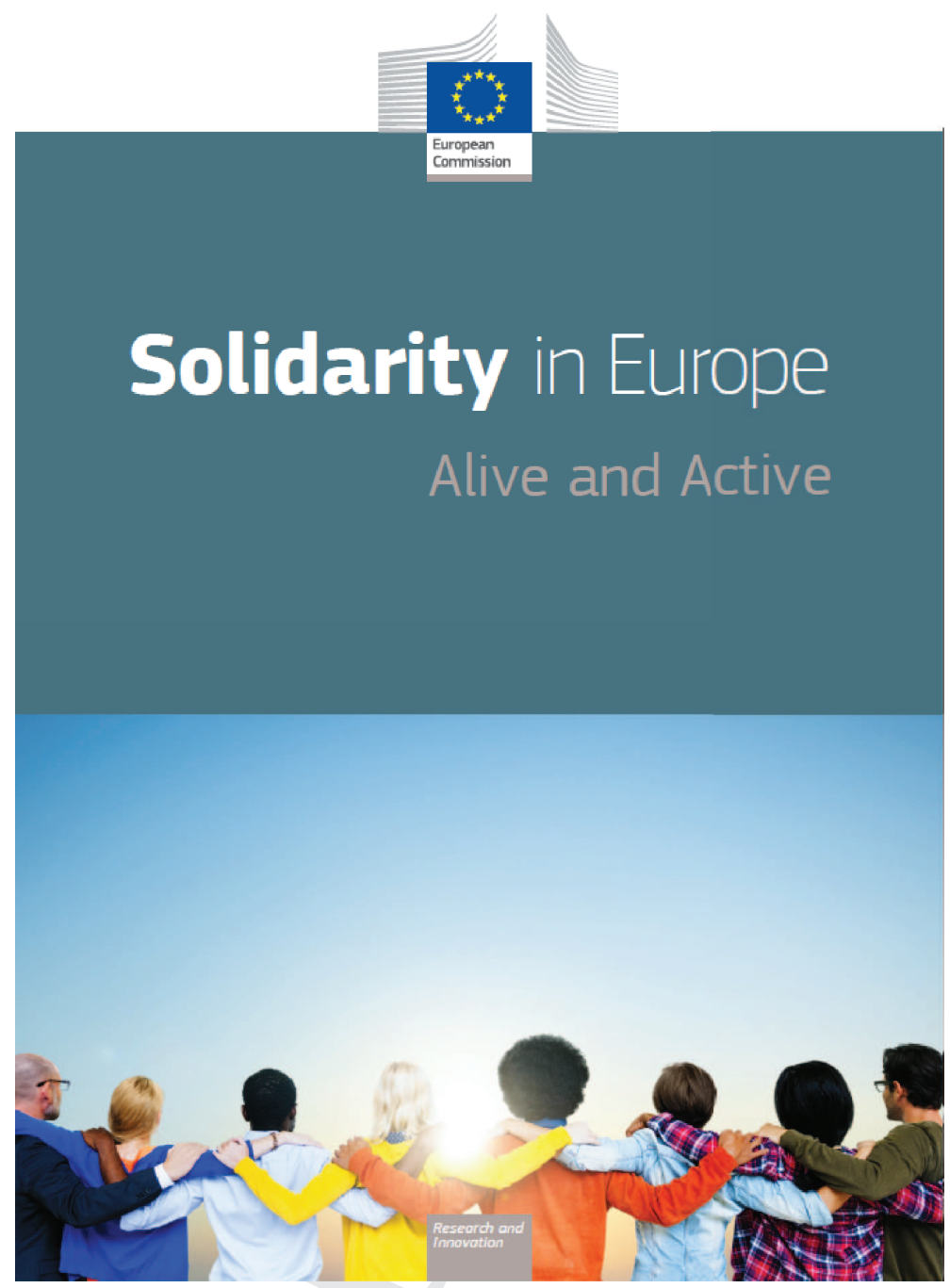

Figure 5.2 European Commission, Solidarity in Europe, 2018. ${ }^{15}$

${ }^{14}$ I. Manners, 'Normative ethics of the European Union', p. 47; I. Manners, 'European communion: political theory of European Union', pp. 482-3.

${ }^{15}$ European Commission, Solidarity in Europe: Alive and Active (2018). 
national/European, cosmopolitan/universal, and some aspects of cosmopolitical/transnational. ${ }^{16}$

\subsection{Communitarian Solidarities within the EU}

The EU may best be conceived as a political object constituted through 'European communion' understood as the extent to which individuals or groups believe themselves to be sharing relations (or not), and the consequences of these beliefs for European political projects, processes, and products. ${ }^{17}$ European communion involves processes of communitarian, cosmopolitan, and cosmopolitical solidarity. ${ }^{18}$ Communitarian theories represent the predominant approach to understanding the EU, with international political theorist Molly Cochran arguing that 'communitarianism is particularist and oriented to shared community life,, ${ }^{19}$ while critical social theorist Craig Calhoun comments that communitarianism suffers from a 'tendency to elide the differences between local networks of social relationships and broad categories of belonging like nations ${ }^{20}$ Writing over four decades ago, Carole Webb introduced a distinction between intergovernmental cooperation, supranational community, and transnational processes in the European communities, which tends to assume communitarian understandings of how communities or groups serve to aggregate their interests. ${ }^{21}$

The myths and narratives of intergovernmental cooperation and solidarity within the EU place emphasis on the idea and motto of being 'united in diversity'. Within the EU the symbols and images of solidarity between Member States is particularly strong in single market, economic, social and territorial cohesion, and energy areas of shared and supporting competences. The iconic images are of geographical maps of the EU setting out the different Member States in bright colours, the sight of

16 European Commission, Solidarity in Europe: Alive and Active (2018), pp. 3 and 9. https:// ec.europa.eu/research/social-sciences/pdf/policy_reviews/solidarity_in_europe.pdf

17 I. Manners, 'European communion: political theory of European Union', pp. 474-5.

18 Ibid., pp. 486-7.

19 M. Cochran, Normative Theory in International Relations: A Pragmatic Approach (Cambridge: Cambridge University Press, 1999), p.8.

20 C. Calhoun, 'The class consciousness of frequent travelers: towards a critique of actually existing cosmopolitanism', in D. Archibugi (ed.), Debating Cosmopolitics (London: Verso, 2003),pp. 86, 96.

${ }^{21}$ C. Webb, 'Introduction: variations on a theoretical theme', in H. Wallace, W. Wallace and C. Webb (eds.), Policy-Making in the European Communities (Chichester: John Wiley \& Sons, 1977), p. 1. 
twenty-eight flags outside EU buildings, together with matching rituals and practices of prime ministers and ministers arriving at the Council of Ministers and European Council to take EU decisions. As the chapters in this volume by Young and Abat Ninet on the Brexit crisis and regionalisation crisis illustrate, these symbols, myths and rituals of Member State communitarian solidarity soon break down when devolved countries, such as the UK or Spain start to break down.

The myths and narratives of supranational community and solidarity within the European community place emphasis on the idea and objective of an 'ever closer union of the peoples of Europe'. Within the EU the symbols and images of European community solidarity goes beyond Member State communities to emphasise solidarity between the peoples of the EU, between women and men, and between generations. In treaty terms, the most iconic symbol of European community is the solidarity clause compelling the Union and its Member States to act jointly in a spirit of solidarity in the event of a terrorist attack, natural- or humanmade disaster. In contrast to the Member State iconography, here the symbolism is of maps of European sub-national regions with brightly coloured regions eligible for structural and cohesion funding. Similarly, the 'symbols of the EU' (flag, anthem, currency, and Europe Day) and their ritualistic use throughout the EU and Eurozone are intended to represent a sense of European community solidarity. Within this volume the chapters by Butler and Snaith on the financial crisis, and Neergaard on the economic crisis, illustrate the way in which the global financial crisis and Eurozone sovereign debt crisis exposed serious differences and absence of European community solidarity on questions of financial regulation and intra-Eurozone transfer mechanisms.

\subsection{Cosmopolitan Solidarities within the EU}

Cosmopolitan theories of the EU have become more important since the end of the Cold War. They involve defining cosmopolitanism as 'universalist and individualist in orientation ${ }^{\prime 22}$ and argue that 'cosmopolitan means belonging to all parts of the world; not restricted to any one country or its inhabitants. ${ }^{23}$ Cosmopolitan theories thus differ from communitarian theories in arguing that concerns for humanity as a whole, or the rights of the individual within humanity, should provide

\footnotetext{
22 Cochran, Normative Theory in International Relations, p. 8.

23 Calhoun, 'The class consciousness of frequent travelers', p. 105.
} 
the basis for understanding solidarity. Cosmopolitan solidarities within the EU tend to be closely associated with liberal rights and mobilities, such as the free movement of goods, persons, services, and capital. A second strand of liberal cosmopolitan theory has focused on Jürgen Habermas's advocacy of deliberative politics through 'communicative action' within the EU public sphere. ${ }^{24}$

The myths and narratives of cosmopolitan solidarity through rights and freedoms within the EU emphasise citizenship of the Union, fundamental rights, and free movement rights. Within the EU the symbols and images of cosmopolitan solidarity are, first, iconographised through the granting of citizenship of the union that is additional to national citizenship, including rights to stand and vote in European Parliament (EP) and local elections, to petition and be heard by the EP and the Ombudsman, and to consular access of any EU consulate around the world. Second, the Charter of Fundamental Rights acts as a touchstone of cosmopolitan solidarity, drawing on treaty references to the 'indivisible, universal values' of human rights, freedom, equality and solidarity. Third, cosmopolitan solidarity is found in the iconic symbol of the right to free movement found in the absence of border controls across the Schengen Area, as well as the symbols of this freedom in standardised border and road signs, drivers' licences and passports. Within this volume the chapters by Lahusen on civic solidarity and Trenz on transnational solidarity mobilisation illustrate the way in which civic solidarity and the public sphere in Europe are important for fostering cosmopolitan solidarity in transnational spaces.

\subsection{Cosmopolitical Solidarities within the EU}

Twenty-first-century critical theories of EU solidarity argue that 'cosmopolitics combine communitarianism with cosmopolitanism ... If cosmopolitanism relies on a discourse of individual rights; communitarianism is based on a discourse of social rights that is often expressed in exclusive and localist terms. Both run the risk of substituting ethics for politics'. ${ }^{25}$ Cosmopolitical solidarities combine

24 J. Habermas, Europe: The Faltering Project (Cambridge: Polity Press, 2009).

25 C. Kinnvall and P. Nesbitt-Larking, The Political Psychology of Globalization: Muslims in the West (Oxford: Oxford University Press, 2011), p.92; Manners, 'Normative ethics of the European Union', p. 67; Manners, 'European communion: political theory of European Union', p. 483. 
agonistic understandings of 'respect' taken from Nietzche by Connolly, ${ }^{26}$ of 'pluralism' taken from Gramsci by Chantal Mouffe, ${ }^{27}$ and of 'contest' taken from Arendt by Bonnie Honig. ${ }^{28}$ Thus agonistic, or radical, cosmopolitical solidarities link local politics with global ethics to provide spaces and places where transnational acts of sharing and contestation between the global and the local are performed. ${ }^{29}$

The myths and narratives of cosmopolitical solidarity within the EU go beyond those of communitarian or cosmopolitan approaches to place emphasis on a 'destiny henceforth shared' between ordinary individuals and groups rather than Member State or supranational communities, or citizenship and individual rights. Within the EU the symbols and images of cosmopolitical solidarity are not produced at the EU or Member State level, but instead are the result of treaty commitments to subsidiarity, local and regional governance. More importantly, genuine acts of cosmopolitical solidarity are at the grass-roots level where non-institutionalised organisations and activists spontaneously take actions in common out of shared concern for fellow human beings in Europe. In treaty terms, the most iconic symbol of cosmopolitical solidarity is found in the principle of subsidiarity where 'decisions are taken as openly as possible and as closely as possible to the citizen'. ${ }^{30}$ This implies that local, grass-roots democracy, policymaking, and action in common are preferable to higher levels of political abstraction. The principle of subsidiarity also suggests a counteracting principle of 'supersidiarity' where 'the Union shall act only if ... the proposed action cannot be sufficiently achieved by the Member States, ... but can rather, .. . be better achieved at Union level' ${ }^{31}$ In other words, this means that 'the Union acts to better achieve together what cannot be achieved apart'. ${ }^{32}$

${ }^{26}$ W. Connolly, Identity/Difference: Democratic Negotiations of Political Paradox (Ithaca, NY: Cornell University Press, 1991), pp. xii-xv.

${ }^{27}$ C. Mouffe, The Return of the Political (London: Verso, 1993), pp.4-6.

${ }^{28}$ B. Honig, Political Theory and the Displacement of Politics (Ithaca, NY: Cornell University Press, 1993), pp.15-16.

29 B. Honig, 'Another Cosmopolitianism? Law and Politics in the New Europe', in S. Benhabib and R. Post (eds.), Another Cosmopolitanism (Oxford: Oxford University Press, 2006), p.117; J. Ingram, Radical Cosmopolitics: The Ethics and Politics of Democratic Universalism (New York: Columbia University Press, 2013), p.18; C. Mouffe, Agonistics: Thinking the World Politically (London: Verso, 2013), pp.43-64.

30 TEU 2010: Arts. 1 and 10

31 TEU 2010: Art. 5

32 Manners, 'European communion: Political theory of European Union', p. 487. 
The iconography of cosmopolitical solidarity is different to the symbols and rituals of communitarian Europe found in maps, flags, anthems, currency or commemoration day, and is different to freedoms and movements of cosmopolitan Europe found in the technologies of mobility. Instead, the formal EU policy of encouraging interregional cooperation through Interreg Europe and the European Regional Development Fund provides the local imagery of projects in research and innovation, small- and medium-sized enterprise competitiveness, low-carbon economy, and environment and resource efficiency. However, since 2016 more grass-roots acts of cosmopolitical solidarity have been driven by the concerns of ordinary people to speak out and take action in common against the reactionary rise of nationalism and the far right across Europe. The 'Pulse of Europe' grass-roots organisation originating in Frankfurt in 2016 has spread political action through regular city demonstrations in favour of a united Europe and opposition to the decline of European democracy. ${ }^{33}$ In Britain similar grass-roots pro-EU organisations and activists erupted in the aftermath of the 2016 advisory referendum in favour of remaining in the EU and opposed to the widespread illegalities, disinformation, and lies of the anti-EU 'Leave' networks of power. ${ }^{34}$ The largest of these activist groups was the 'People's Vote' group advocating a second referendum and organising a London anti-Brexit demonstration of approximately one million people in March 2019. ${ }^{35}$ What these movements, and the myriad of pro-unity movements such as Another Europe is Possible, DiEM25, Volt Europa, European Democracy Lab, My Country? Europe, 89 Initiative and many others suggest is that there is some evidence of genuine acts of cosmopolitical solidarities within the EU. ${ }^{36}$ The chapters by Schiek on solidarity

33 Pulse of Europe 'What is at Stake?' (2019), available at: https://pulseofeurope.eu/en/whatis-at-stake/; M. Cottakis, 'Can Europe save itself?', Washington Post, 1 October 2018.

34 Z. Williams, 'There's only one way to stop Brexit: from the ground up', The Guardian, 29 August 2018.

35 J. Chaffin, 'Britain's Europhiles splinter into dozens of grassroots movements', Financial Times, 8 December 2016; A. Rawnsley, 'The anti-Brexiters can get by without a leader. But not without a plan', The Guardian, 25 November 2018; B. Mueller and P. Karasz, 'Angry over Brexit stalemate, huge crowds march in London to demand second vote', New York Times, 23 March 2019; P. Mason, 'To defeat an insurgent far-right, Labour must resist Brexit with all its force', New Statesman, 27 March 2019; People's Vote, 'Who we are' (2019), available at: https://www.peoples-vote.uk/who_we_are.

${ }^{36} \mathrm{H}$. Kaschel, 'The pro-Europe grassroots movements aimed at saving the EU', Deutsche Welle, 1 April 2017; 'Volt wants to become the first pan-EU political party', The Economist, 1 November 2018; Y. Varoufakis and D. Adler, 'The European spring holds the answer to the fragmenting EU's plight', The Guardian, 11 March 2019. 
in the case law of the European Court of Justice and Zhang on free movement and social citizenship in the EU both illustrate the way in which solidarity between citizens and contestation of the social rights of migrants can contribute towards a more critical, cosmopolitical understanding of transnational solidarity from the ground up.

\section{Transnational Solidarity across the EU's Borders}

Discussions of solidarity across the borders of the EU have grown in the study of EU relations with, and concern for, its neighbours through the European Neighbourhood Policy (ENP) since 2004 and the European refugee crisis of 2015. ${ }^{37}$ The European External Action Service Fact Sheet on 'Europe - the Continent of Solidarity ${ }^{38}$ (Figure 5.3), together with an accompanying 'Joint Statement on the occasion of International Migrant Day'," ${ }^{39}$ illustrate how the analysis of transnational solidarity within the EU must also take account of transnational solidarity across the EU's borders, including communitarian, cosmopolitan and cosmopolitical dimensions.

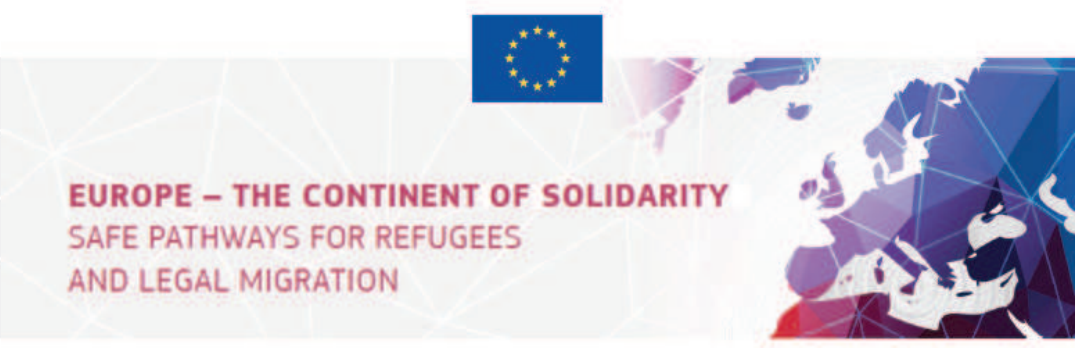

Figure 5.3 EEAS, Europe - the Continent of Solidarity, 2018.

37 R. Whitman and S. Wolff (eds.), The European Neighbourhood Policy in Perspective: Context, Implementation and Impact (London: Palgrave, 2010); S. Poli (ed.), The European Neighbourhood Policy: Values and Principles (London: Routledge, 2018); A. Grimmel and S. Giang (eds.), Solidarity in the European Union: A Fundamental Value in Crisis (Berlin: Springer, 2017); D. della Porta (ed.), Solidarity Mobilizations in the 'Refugee Crisis': Contentious Moves (Basingstoke: Palgrave, 2019).

38 European External Action Service (EEAS), 'Europe - the Continent of Solidarity', 28 March 2018, available at: https://eeas.europa.eu/sites/eeas/files/migration_opportuni ties_protection_us.pdf.

39 European Commission, 'Europe - the continent of solidarity: Joint Statement on the occasion of International Migrant Day’ (2017) Statement/17/5344, 18 December. 
Analyses of solidarities across the borders of Europe are further complicated by the fact that the EU is not the only pan-European regional organisation. The Council of Europe (CoE), the Organization for Security and Co-operation in Europe (OSCE), and the North Atlantic Treaty Organization (NATO), as well as many other social and cultural organisations all have cross-cutting membership across the EU. Therefore, the apparently simple question of transnational solidarity across the EU's borders immediately runs into the challenge of whether this includes solidarity with the four European Free Trade Association members of Schengen, the other nineteen members of the CoE, or the other members of organisations such as the OSCE/NATO? This question is further complicated by social, cultural, and sporting associations that reach far beyond a narrow EU understanding of Europe including, for example, Armenia, Azerbaijan, Georgia, Israel, Russia, Turkey, and Ukraine participating in events such as the UEFA football championships and the Eurovision song contest.

\subsection{Communitarian Solidarities across the EU's Borders}

The myths and narratives of communitarian solidarities across the EU's borders expose a series of sharp distinctions between Member State versus $\mathrm{EU}$ communities, and between partnership versus security. These distinctions are captured in TEU Art. 8 and Commission document on ENP declaring special relationships and good neighbourliness, but focusing on stability and security, particularly for the EU. ${ }^{40}$ Similarly, the Commission's 2015 'European Agenda on Migration', as well as its 2017 Joint Statement declared the principles of solidarity and shared responsibility and a continent of solidarity, but focused on securing borders and international protection. The iconic imagery of the crises of solidarity across the EU's borders are represented by the Arab uprisings of 2010/11 and the related refugee crises of 2015/16. The symbolism of North African and Middle Eastern peoples' rising up against twenty governments is captured by the images of massed protesters in places such as Tahir Square, Egypt.

${ }^{40}$ European Commission, 'European Neighbourhood Policy Strategy Paper' (2004) COM (2004) 373 final, 12 May 2004; European Commission and European External Action Service, 'Neighbourhood at the Crossroads: Implementation of the European Neighbourhood Policy in 2013', Joint Communication JOIN(2014) 12 final, Brussels, 27 March 2014. 
Following the repressive reactions to these protests and related civil wars in Yemen, Libya, Iraq and Syria, from 2014 the symbolism increasingly became of refugees and asylum seekers crossing the Mediterranean in rubber boats or washing up drowned on European coasts. In the uprisings and the refugee crisis, the communitarian solidarities within the EU, between Member States, and across the EU's borders, raised the question of whether EU transnational solidarity has left 'Europe at Sea'? ${ }^{41}$ As the chapter by Thielman on making responsibility-sharing initiatives more effective in the context of the refugee crisis illustrates, these symbols, myths, and rituals of EU communitarian solidarity soon break down under fast-moving conditions of crisis.

\subsection{Cosmopolitan Solidarities across the EU's Borders}

Similar to the previous discussion, the myths and narratives of cosmopolitan solidarities across the EU's borders are found in the questions of neighbourliness and migration. However, here the distinctions are between Member States, governments, and political parties who take a more cosmopolitan approach to the rights and concerns of non-EU citizens versus those who take a less cosmopolitan approach to excluding foreigners and denying rights. The responses to the 2015 refugee crisis demonstrate these distinctions through open arms and signs of 'refugees welcome', swiftly followed by razor-wire fences and signs of 'refugees not welcome'.

The data from 2015 tells this story well: over 1.2 million asylum seekers registered in the EU, mostly from Syria $(363,000)$, Afghanistan $(178,000)$ and Iraq $(121,000){ }^{42}$ Of those asylum seekers, the largest number registered in Germany $(442,000)$, Hungary $(174,000)$, Sweden $(156,000)$, Austria $(85,000)$, Italy $(83,000)$ and France $(71,000)$. In per capita terms (per million inhabitants), the greatest number of asylum applications was in Hungary $(18,000)$, Sweden $(16,000)$, Austria $(10,000)$, Norway $(5,900)$, Finland $(5,900)$ and Germany $(5,400) .{ }^{43}$ In September 2015 EU ministers reached agreement on relocation of asylum seekers and burden sharing in the EU. ${ }^{44}$ This meeting and subsequent disagreements represents an iconic moment in the collapse of cosmopolitan solidarity across the

41 A. Piras (director), Europe at Sea (London: Journeyman Pictures, 2017).

42 Eurostat, 'Asylum in the EU Member States: Record number of over 1.2 million first time asylum seekers registered in 2015' 44 (2016), 4 March news release.

43 Ibid.

${ }^{44}$ Council of the EU, 'Justice and Home Affairs Council', 22 September 2015. 
borders of the EU. In terms of per capita asylum seekers (per million inhabitants) Czechia (100), Hungary (18,000), Romania (60) and Slovakia (50) voted against the relocation plan, Finland $(5,900)$ abstained, while the UK (600), Ireland (700) and Denmark (3,700) opted out of burden sharing. ${ }^{45}$ In October and November 2015 Member States from north to south introduced restrictive border controls on refugees, while in March 2016 the EU negotiated an agreement with Turkey to restrict refugees reaching Greece. ${ }^{46}$ These Member State disagreements, the closing of borders, and the EU-Turkey agreement marked the end of cosmopolitan solidarities for refugees across the borders of the EU. The associated growth of far-right movements and parties in most EU Member States has affected government formation in Hungary, Poland, Italy, France, Sweden, and the UK, and shapes internal politics across Europe.

\subsection{Cosmopolitical Solidarities across the EU's Borders}

Unlike communitarian or cosmopolitan approaches, agonistic cosmopolitics demand a radically different approach to transnational solidarities across the EU's borders. Instead of prioritising the local of communitarian solidarities or prioritising the global of cosmopolitan solidarities, radical agonistic cosmopolitical solidarities link global ethics of emancipation and empathy with local politics of relationships and actions. Within the approach, the myths and narratives of cosmopolitical solidarities across the EU's border are driven by grass-roots activists and groups rather than EU institutions, as six examples of refugee rescue, solidarity, youth response, welcome, artistic response, and activism illustrate.

European non-governmental organisations (NGOs) and volunteer associations run search and rescue ships such as The Aquarius operated by SOS Mediterranee and Médecins sans Frontières; the Mo Chara operated by Refugee Rescue; the Open Arms operated by Proactiva Open Arms; the Sea-Watch 3 operated by Sea-Watch; the Alan Kurdi operated by Sea-Eyes, and at least 15 NGOs recognised by the Search and Rescue Observatory for the Mediterranean. ${ }^{47}$ European city authorities and universities organise

45 S. Erlanger and J. Kanter, 'Plan on migrants strains the Limits of Europe's unity', New York Times, 22 September 2015.

46 European Council, 'EU-Turkey statement', 18 March 2016.

47 T. Embury-Dennis, 'Médecins sans Frontières forced to pull rescue boat from Mediterranean after being stuck in port for months', Independent, 7 December 2018; L. Tondo, 'Italian authorities order seizure of migrant rescue ship', The Guardian, 20 March 2019. 
solidarity and support for refugees. The Eurocities' 'Solidarity Cities' initiative provides refugee reception and integration with thirty-eight European cities signing the 'Eurocities Integrating Cities Charter. ${ }^{48}$ Similarly, the European University Association 'Refugees Welcome' initiative help to provide shelter, advice and support in 350 intuitions spread across thirty-two countries. ${ }^{49}$ Youth associations such as 'Time to be welcome', made up of ten European youth organisations (in particular the Scouts) welcome youth refugees, as well as other grass-roots organisations such as 'Welcome Refugees International' encouraging flatsharing with refugees in thirteen European countries. ${ }^{50}$

At the same time, an interesting reversal of 'welcomeness' has recently occurred alongside negative responses to overtourism and private tourist exploitation with graffiti announcing 'tourists go home, refugees welcome' in Barcelona, Malaga, Berlin, Venice, Amsterdam, Lisbon and beyond. ${ }^{51}$ The art world has also had a more welcoming approach to refugees, with a series of symbolic interventions on refugees and their art. Installations have included Ai Weiwei's 2016 'translocation - transformation' discarded life jackets floating in the pond at Vienna's Belvedere Palace; Doris Salcedo's 2018 'Palimpsest' stone-water memorial for drowned migrants at Madrid's Palacio de Cristal; Amnesty International's 2019 projection of 'refugees welcome' on the Athen's Acropolis; and the Venice Biennial's 2019 'Rothko in Lampedusa' refugee art display. ${ }^{52}$ Banksy's graffiti art is significant in this respect with the 2014 racist pigeons graffiti in Clacton-on-Sea, England; the 2015 Steve Jobs Syrian migrant in 'the jungle' Calais; the 2015 raft of refugees in Calais inspired by Gericault's 'Raft of the Medusa'; Weston-Super-Mare's 2015 'Dismaland' refugee boats installation; and the 2018 graffiti critical of the French response to the refugee

${ }^{48}$ Solidarity Cities. 'About' (2016), available at: https://solidaritycities.eu/about; Integrating Cities, 'Eurocities Integrating Cities Charter' (2018), available at: http://www integratingcities.eu/integrating-cities/charter.

49 European University Association, 'Refugees Welcome Map' (2018).

50 Time to be Welcome, 'Background: Migration in Europe' (2018), available at: http://timetobewelcome.eu/the-project/migration-in-europe/; Refugees Welcome International, 'Refugees Welcome' (2018), available at https://www.refugees-wel come.net/.

51 S. Burgen, "Tourists go home, refugees welcome": why Barcelona chose migrants over visitors', The Guardian, 25 June 2018; 'Wish you weren't here: the backlash against overtourism', The Economist, 25 October 2018.

${ }^{52}$ E. Povoledo, 'Wreck of migrant ship that killed hundreds will be displayed at Venice Biennale', New York Times, 6 May 2019. 
crisis in Paris. ${ }^{53}$ The symbols and myths of this cosmopolitical transnational activism and actions in support of solidarity across the EU's border illustrate the ways in which the rescue of, youth support for, and artistic production produce solidarity and welcome refugees, often against the wishes of EU Member States.

\section{Transnational Solidarity beyond the EU}

Discussions of solidarity beyond the EU pre-date those of solidarity within and across the EU's borders with, for example, extensive post-Cold War examinations of EU 'social solidarity' in the context of the normative power approach to the EU. ${ }^{54}$ The symbol and myth of the solidarity jar acted as the banner and icon of the 2000 Cotonou Agreement between the $\mathrm{EU}$ and the African, Caribbean and Pacific (ACP) countries (Figure 5.4). The accompanying description illustrates how symbols and myths of transnational solidarity beyond the $\mathrm{EU}$ are important:

\section{The symbolism of the solidarity jar}

The symbol chosen by the host country to illustrate the Cotonou Agreement simultaneously embodies the power of union and the importance of solidarity - the pierced jar will hold water only if all the people come together to plug its holes with their fingers. This symbolic image, borrowed from Ghezo, former king of Dahomey (as Benin used to be known), fits perfectly with the values which have always underpinned relations between the European Union and the ACP countries - values which are now more than ever crucial to the success of the future partnership. ${ }^{55}$

The symbolism and myth of the solidarity jar illustrate how the analysis of transnational solidarity beyond the EU must include the communitarian 'power of union', the cosmopolitan 'importance of solidarity', and cosmopolitical acts when 'people come together'.

${ }^{53}$ H. Ellis-Petersen, 'Banksy uses Steve Jobs artwork to highlight refugee crisis', The Guardian, 11 December 2015.

54 I. Manners, 'Normative power Europe: a contradiction in terms?', Journal of Common Market Studies, 40(2) (2002), 242-43, 235; Manners, 'Normative ethics of the European Union', pp. 46-53; C. Bretherton and J. Vogler, The European Union as a Global Actor, 2nd edn. (London: Routledge, 2005); R. Whitman (ed.), Normative Power Europe: Empirical and Theoretical Perspectives (London: Palgrave, 2011); A. Hadfield, I. Manners and R. Whitman (eds.), Foreign Policies of EU Member States (London: Routledge, 2017).

${ }^{55}$ European Commission, 'The symbolism of the solidarity jar' (2000) September ACP-EU Courier, Special Issue on the Cotonou Agreement. 


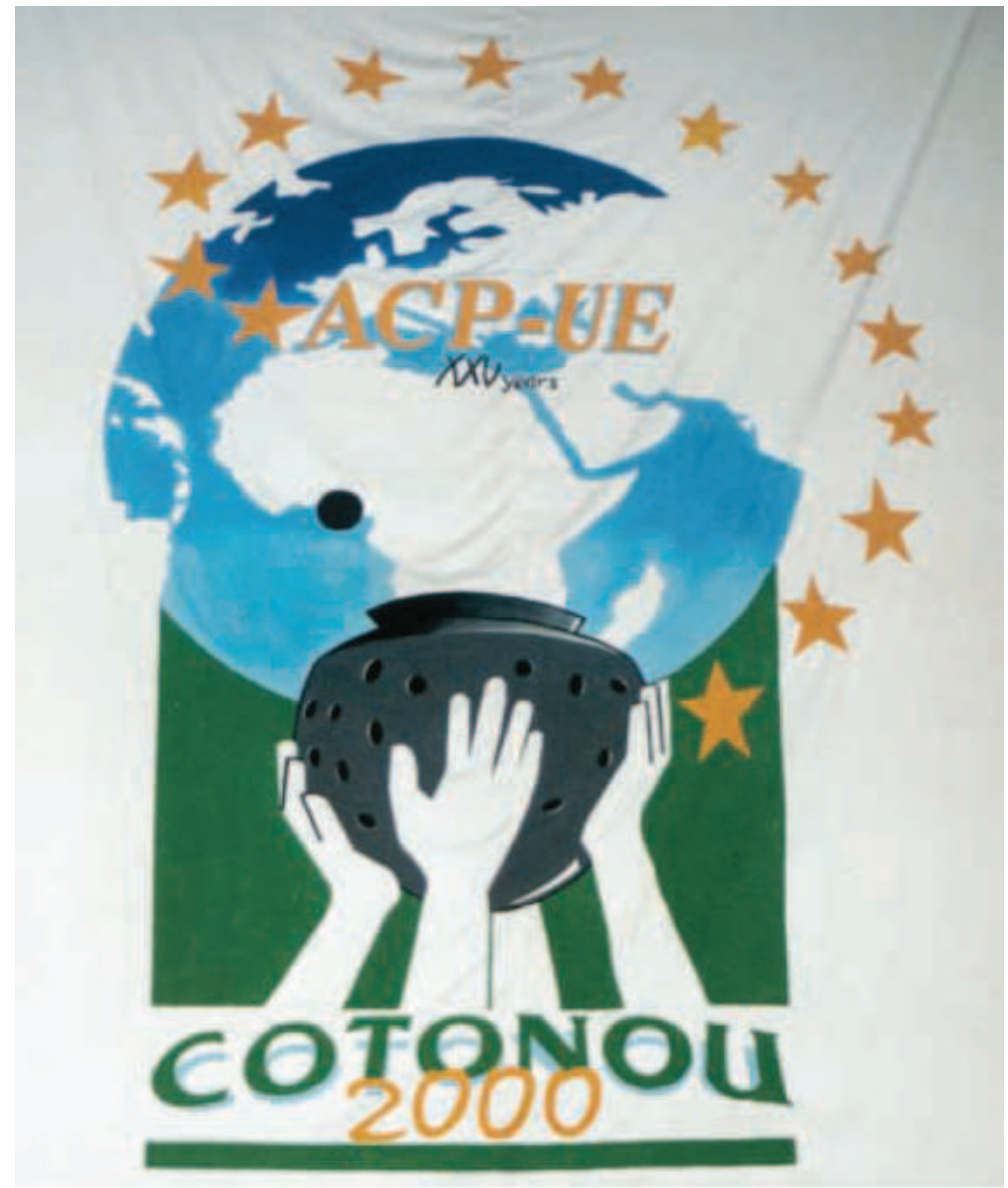

The symbolism of the solidarity jar

Figure 5.4 European Commission, ACP-EU Courier, $2000 .^{56}$

\subsection{Communitarian Solidarities beyond the EU}

The myths and narratives of communitarian solidarity beyond the EU demonstrates the politics of European communion through the tensions, for example, between Member State solidarities with non-members and EU solidarities with other regional integration organisations. These

56 European Commission, 'The symbolism of the solidarity jar' (2000) September ACP-EU Courier, Special Issue on the Cotonou Agreement. 
myths are given iconic status within the TEU that now states under the general provisions on the Union's External Action that:

The Union's action on the international scene shall be guided by the principles which have inspired its own creation, development and enlargement, and which it seeks to advance in the wider world: democracy, the rule of law, the universality and indivisibility of human rights and fundamental freedoms, respect for human dignity, the principles of equality and solidarity, and respect for the principles of the United Nations Charter and international law. ${ }^{57}$

In this communitarian reading of its external actions, the principle of solidarity is part of promoting principles which have inspired the EU's creation, development and enlargement, rather than an explicit act of transnational solidarity. It is within this context that the tensions arise between Member State foreign policies through the Common Foreign and Security Policy, and EU external actions through the broader development and enlargement policies of the European External Action Service (EEAS). ${ }^{58}$ In this respect the EU's development policy symbolises communitarian solidarity beyond the EU with its emphasis on addressing the 2015 UN Sustainable Development Goals through development assistance, in particular through the narrative of 'Europe remains the world's biggest development donor'. ${ }^{59}$

\subsection{Cosmopolitan Solidarities beyond the EU}

While the myths and narratives of cosmopolitan solidarities beyond the $\mathrm{EU}$ are also given iconic status in the TEU within the common provisions, their emphasis is different:

In its relations with the wider world, the Union shall uphold and promote its values and interests and contribute to the protection of its citizens. It shall contribute to peace, security, the sustainable development of the Earth, solidarity and mutual respect among peoples, free and fair trade, eradication

57 TEU, Art. 21.1 (2016), emphasis added.

58 A. Hadfield, I. Manners, and R. Whitman (eds.), Foreign Policies of EU Member States, pp. $10-16$.

59 I. Manners, 'The normative power of the European Union in a globalised world' in Z. Laïdi (ed.),EU Foreign Policy in a Globalized World: Normative Power and Social Preferences(London: Routledge, 2008), pp. 24-31; I. Manners, 'Den Europeiska unionen i en globaliserande värld', in Rikard Bengtsson, Ian Manners, Hans-Åke Persson, Linda Gröning and Ola Zetterquist (eds.), Det europeiska projektet: politik och juridikhistoria och framtid (Malmö: Liber, 2013), pp.216-230, 209,; European Commission (2019) 'Europe remains the world's biggest development donor - $€ 74.4$ billion in 2018', DG DEVCO, 11 April 2019. 
of poverty and the protection of human rights, in particular the rights of the child, as well as to the strict observance and the development of international law, including respect for the principles of the United Nations Charter. ${ }^{60}$

In a cosmopolitan reading of the EU's relations with the wider world, the aim is not simply to promote its own communitarian values and interests but to also promote cosmopolitan solidarity and mutual respect among peoples (not states), protect human and children's' rights, and to observe and develop international law and the principles of the UN charter. Thus, the communitarian emphasis on the EU's own principles, values, and interests are tempered by the cosmopolitan contribution to the wider world led by the principles of the $\mathrm{UN}$ emphasising mutual respect, equality and solidarity, as well as human rights, democracy, and the rule of law more generally. An iconic illustration of cosmopolitan solidarity is the attempt by Sweden's first EU presidency, and subsequent foreign policy, to place an emphasis on 'an internationally active union based on the principle of solidarity'. ${ }^{61}$ This notion of solidarity in EU foreign policy included an equal emphasis on human rights, European security and defence policies, and development cooperation, with a particular emphasis on gender equality.

\subsection{Cosmopolitical Solidarities beyond the EU}

Radical or agonistic cosmopolitical approaches to transnational solidarities beyond the EU shift the focus away from the Member States, institutions, and treaties of the EU. Instead, the focus is placed on networks and actions that are distinctly translocal in terms of principles, actions, and impact. Within this approach, the myths and narratives of cosmopolitical solidarities beyond the EU are not a function of the EU, its Member States, or its policies, but are the ongoing result of millions of EU citizens trying to raise consciousness and change policies on the greatest global political challenge of the twenty-first century; climate crisis.

Since the stark inevitability of $2^{\circ} \mathrm{C}$, with an increased probability of $3^{\circ} \mathrm{C}$, global warming was made clear in 2018, increasingly numbers of grassroots activists and groups are taking a lead in Europe in trying to change minds and policies. ${ }^{62}$ The School Strike for Climate movement, started by

60 TEU 2016, Art. 3.5, emphasis added.

${ }^{61}$ Swedish Minister for Foreign Affairs, Programme of the Swedish presidency of the European Union, 1 January to 30 June 2001. Draft 2000-07-07.

${ }^{62}$ Intergovernmental Panel on Climate Change (IPCC), Global Warming of $1.5^{\circ} \mathrm{C}$. (Geneva: IPCC, 2018); A. Raval and L. Hook 'Paris climate pact aims fading, warns IEA', The Financial Times, 15 May 2019. 
Greta Thunberg in August 2018, and the Extinction Rebellion (XR) launched in October 2018 both serve as illustrations of how symbols and myths of transnational solidarity are enacted within and beyond the EU. ${ }^{63}$ Since November 2018 over a million school children in 2,000 cities have participated in school strikes worldwide, accelerated by the first Global Climate Strike for the Future on 15 March 2019 and their call for politicians to listen to the 'climate crisis and a betrayed generation'. ${ }^{64}$ In addition to school strikes in the majority of EU Member States, there have been strikes in at least twenty non-EU countries around the world. Remarkably, these networks of school student solidarity have been coordinated via social media by youth groups such as 'Fridays for Future', 'School Strike 4 Climate', and 'Youth for Climate'. ${ }^{65}$ These school strikes appear to be having some effect with Greta Thunberg being asked to speak in the European Commission, the EP, and the UK Houses of Parliament. ${ }^{66}$

At the same time as the school strikes for climate were spreading across the world, the XR movement started taking non-violent direct action in the UK during 2018, spreading across Europe and beyond in 2019. While similar to the school strike movement, XR is a grass-roots mass political direct action movement with three specific aims:

01. Tell the truth: Government must tell the truth by declaring a climate and ecological emergency, working with other institutions to communicate the urgency for change.

02. Act Now: Government must act now to halt biodiversity loss and reduce greenhouse gas emissions to net-zero by 2025 .

03. Beyond Politics: Government must create and be led by the decisions of a Citizens' Assembly on climate and ecological justice. ${ }^{67}$

${ }^{63}$ G. Thunberg, 'Vi vet - och vi kan göra något nu', Svenska Dagbladets, 30 May 2018; A. Green, M. Scott Cato, et al. 'Facts about our ecological crisis are incontrovertible. We must take action', The Guardian, 26 October 2018.

${ }^{64}$ Global coordination group of the youth-led climate strike, 'Climate crisis and a betrayed generation', The Guardian, 1 March 2019.

65 S. Laville, M. Taylor and D. Hurst, "It's our time to rise up': youth climate strikes held in 100 countries', The Guardian, 15 March 2019.

${ }^{66}$ G. Thunberg, "You did not act in time": Greta Thunberg's full speech to MPs', The Guardian, 23 April 2019; G. Rankin, 'Greta Thunberg tells EU: your climate targets need doubling', The Guardian, 21 February 2019; G. Rankin, 'Forget Brexit and focus on climate change', Greta Thunberg tells EU', The Guardian, 16 April 2019.

67 Extinction Rebellion, 'Our demands' (2018), available at: https://rebellion.earth/the-truth /demands/. 
In December 2018 XR expanded beyond the UK to include a call to action by 100 academics, authors, politicians and campaigners from across the world to address climate crisis, with XR events in the Netherlands, Germany, Austria, Belgium, Sweden, Spain, Switzerland and outside Europe to large actions in Australia, the USA and beyond. ${ }^{68}$ The combination of school strikes and XR appear to be having some effect in some EU Member States with European Commission President, Jean-Claude Juncker telling Greta Thunberg that his proposal for the coming EU budget (2021-27) had a target of 25 per cent of spending to go on 'action to mitigate climate change'. ${ }^{69}$ In May 2019 eight Member States at the forefront of climate change (Belgium, Denmark, France, Luxembourg, the Netherlands, Portugal, Spain, Sweden) subsequently supported Juncker's 25 per cent climate change spending target and pushed for netzero EU emissions by 2050, while the UK became the first country in the world to declare a climate emergency. ${ }^{70}$

These grass-roots organisations and networks of school strikes and XR direct action illustrate the ways in which cosmopolitical transnational activism within the $\mathrm{EU}$ is directly linked to action and concern beyond the EU. The centrality of myths and narratives such as 'school strike', 'Fridays for future', the 'betrayed generation', and well as XR and 'system change not climate change', go hand-in-hand with the images of thousands of school children on the streets and XR direct action against unsustainable practices.

\section{Conclusion: Symbols and Myths of EU Transnational Solidarity}

This chapter has drawn on three decades of analysing the EU in global politics in order to analyse and differentiate between solidarities within, across the borders of, and beyond the EU. It argues the need to use the work of Carol Gould in order identify transnational EU solidarities as overlapping networks of relations that share and support actions to eliminate oppression or reduce suffering within, across the borders of, and beyond the EU. As the three

${ }^{68}$ V. Shiva, N. Klein, et al., 'Act now to prevent an environmental catastrophe', The Guardian, 9 December 2018; J. Watts, 'Extinction Rebellion goes global in run-up to week of international civil disobedience', The Guardian, 10 December 2018.

69 C. Roth, 'Swedish student leader wins EU pledge to spend billions on climate', Reuters, 21 February 2019.

70 R. Toplensky, 'Eight EU nations push for net-zero emissions in bloc by 2050', The Financial Times, 8 May 2019; 'UK Parliament declares climate change emergency', BBC News, 1 May 2019. 
examples of grass-roots activist groups and networks in support of the EU, in support of refugees, and in support of climate action have illustrated, there is evidence of cosmopolitical transnational EU solidarities that network and share global ethics with local politics that are more likely to take actions in concert that are caring and empathic towards distantly situated others.

The final symbol and myth of EU transnational solidarities is of Aylan Kurdi's aunt, Tima Kurdi and Luis Morago, campaign director for Avaaz, standing in front of the 'Welcome Wall' on Rond Point Schuman in September 2015 to deliver a 1 million signature online petition to the EU to take action to welcome refugees (Figure 5.5). This petition, demonstration, and action helped push the EU Council President Donald Tusk to convene an extraordinary informal European Council meeting on 23 September 2015 to address the 'unprecedented number of migrants and refugees arriving in Europe.. ${ }^{71}$ What this symbolic image of Alyan

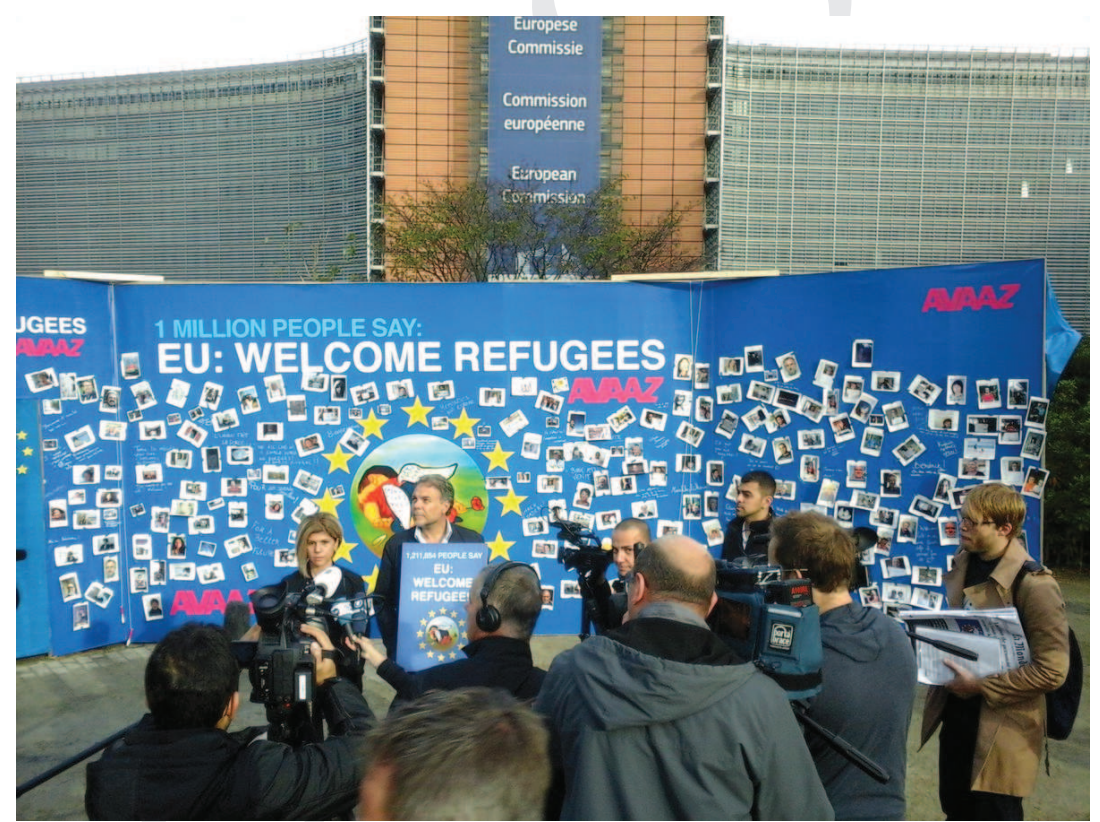

Figure 5.5 Avaaz, EU: Welcome Refugees, 2015. ${ }^{72}$

${ }^{71}$ European Council, 'Statement on the Informal meeting of EU heads of state or government on migration', 23 September 2015.

72 Avaaz, 'We're in Brussels delivering over $1 \mathrm{M}$ voices calling on the EU to make \#RefugeesWelcome today with Aylan Kurdi's Aunt', 14 September 2015, available at: https://twitter.com/Avaaz/status/643341985647075328. 
Kurdi, the million messages of welcome, the Welcome Wall, the online activism, and the media event in front of the European Commission and Council of Ministers' buildings on the EU's most central roundabout show is that with the facilitation of Avaaz, a powerful online activist network, genuine transnational EU solidarity is possible.

The examples discussed throughout this chapter help demonstrate the importance of networks of relations, shared goals, empathy with distant others, and action in concert in support of others. But the symbols and images, myths and narratives, of such acts of transnational solidarity are not simply propaganda, media manipulation, or false consciousness of solidarity with others. They are a central component of mobilising, expressing, and demonstrating transnational solidarity in order to eliminate oppression or reduce suffering, whether through discrimination, exclusion, or ecological catastrophe. 